Syntax Literate: Jurnal Ilmiah Indonesia p-ISSN: 2541-0849

e-ISSN: 2548-1398

Vol. 5, No. 8, Agustus 2020

\title{
TRADISI DALAM BINGKAI REALITAS SOSIAL-KEAGAMAAN: STUDI KASUS HAUL KI NEWES INDRAMAYU
}

\section{Taufiq Zaenal Mustofa}

STKIP Pangeran Dharma Kusuma Indramayu, Indonesia

Email: taufikzaenalmustofa@gmail.com

\section{Abstract}

Tradition is a part of the culture that often appears in the course of human life. One tradition that is still alive among the people, especially Muslims, is haul. Haul Ki Newes Indramayu is one of them. Haul which later became a social and religious reality of the community has been running for decades. How then a tradition can survive and take root in society is a question for researchers. The researcher used a descriptive qualitative approach based on Max Weber's theory of action to answer that big question. From the results of the study, it was found that the tradition of Ki Newes haul had become a community trust in Kedungwungu Village, Krangkeng, Indramayu and it was hereditary. Haul Ki Newes has two goals. First, as a tribute and thanks to the ancestors who have fought for their religion. Second, as an intermediary to get closer to Allah SWT. The ultimate goal is the fulfillment of all intentions.

Keywords: Haul tradition; Ki Newes; social; religious reality

\begin{abstract}
Abstrak
Tradisi adalah bagian dari kebudayaan yang seringkali muncul dalam perjalanan kehidupan manusia. Salah satu tradisi yang masih hidup di kalangan masyarakat khususnya umat muslim adalah haul. Haul Ki Newes Indramayu salah satunya. Haul yang kemudian menjadi sebuah realitas sosial keagamaan masyarakat tersebut sudah berjalan puluhan tahun. Bagaimana kemudian sebuah tradisi bisa bertahan dan mengakar di masyarakat. Peneliti menggunakan pendekatan kualitatif deskriptif berdasarkan teori tindakan Max Weber untuk menjawab pertanyaan besar tersebut. Dari hasil penelitian ditemukan, bahwa tradisi haul Ki Newes telah menjadi kepercayaan masyarakat Desa Kedungwungu Kecamatan Krangkeng Kabupaten Indramayu dan bersifat turun temurun. Haul Ki Newes memiliki dua tujuan. Pertama, sebagai penghormatan dan ucapan terima kasih pada para leluhur yang telah berjuang. Kedua, sebagai perantara untuk mendekatkan diri kepada Allah SWT. Tujuan akhirnya adalah terkabulkannya semua hajat.
\end{abstract}

Kata kunci : Ki Newes; Tradisi Haul; realitas sosial keagamaan

\section{Pendahuluan}

Penyebaran agama Islam di Indonesia sampai Islam berkembang dengan pesat tidak lepas dari peranan ulama-ulama dari tanah Arab. Perkembangan Islam sampai zaman modern sampai sekarang bukti-bukti peninggalan ulama itu masih banyak yang 
belum diungkap secara formal dalam bentuk penelitian oleh sejarawan. Ulama mempunyai posisi tersendiri dalam masyarakat Islam, meskipun telah terjadi beberapa perubahan dalam bidang penekanan dan bidang garapannya, mereka tetap memiliki posisi penting sampai sekarang (Putri, 2018). Di Pulau Jawa dikenal dengan Wali Songo sebagai tokoh yang berhasil mengembangkan agama Islam sedangkan di daerah Cirebon, Indramayu, dan sekitarnya yang terkenal dan sukses sebagai pembawa agama Islam, yaitu Sunan Gunung Jati (Qomariyah, 2019).

Setelah Sunan Gunung Jati meninggal dunia penyebaran agama Islam diteruskan oleh keturunan dan santri-santri Sunan Gunung Jati. dari salah satu santri Sunan Gunung Jati ialah Ki Royani yang di kenal dengan nama Ki Geden Srengseng yang menyebarkan agama Islam di wilayah Indramayu bagian timur tepatnya yang sekarang menjadi Desa Srengseng sebelum terjadi pemekaran desa. Ki Royani mempunyai santri dari Demak yang bernama Ki Mridin dan Ki Karang, keduanya di tugaskan di wilayah yang sekarang menjadi Desa Kedungwungu setelah terjadi pemekaran dari Desa Srengseng. Ki Mridin mempunyai anak bernama Ki Newes sedangkan Ki Karang mempunyai anak bernama Nyi Newes, lalu mereka dinikahkan. Sampai akhirnya meninggal di Desa Kedungwungu. Seperti tradisi masyarakat Jawa yang menghormati leluhurnya dengan doa bersama yang di sebut haul, demikian halnya masyarakat Desa Kedungwungu mengadakan haul setiap satu tahun sekali untuk mengenang jasa dan mengharapkan karomahnya.

Haul adalah suatu trdisi yang berkembang kuat di kalangan nahdiyin. Berbentuk peringatan kematian seseorang setiap tahun (Mufidah, 2016). Biasanya dilakukan tepat pada hari, tanggal dan bulan kematiannya. Sedangkan Tradisi atau kebudayaan adalah kompleks yang mencakup pengetahuan, kepercayaan, kesenian, moral, hukum, yang merupakan adat istiadat serta lain-lain yang berkaitan dengan kemampuan dan kebiasaan sebagai anggota masyarakat (Soekanto, 2009). Selo Soemardi seperti dikutip Purwanto, mengemukakan bahwa kebudayaan adalah semua hasil cipta, karsa, rasa dan karya manusia dalam masyarakat (Purwanto, 2007). Istilah haul sering digunakan di dalam kegiatan-kegiatan urusan zakat, yakni zakat suatu barang yang harus dikeluarkan apabila telah mencapai genap satu tahun (haul). Sedangkan pengertian yang biasa berlaku di tengah-tengah masyarakat Islam di Indonesaia dan khususnya di Jawa, istilah haul biasanya diartikan pada tiap-tiap tahun (setahun sekali) atas wafatnya seorang yang telah dikenal sebagai pemuka agama, wali, ulama atau para pejuang Islam (Hoeve, 2003).

Di era modern seperti sekarang ini yang ditandai dengan industrialisasi memiliki pengaruh yang sangat besar bagi keberlangsungan tradisi yang berkembang di tengah masyarakat (Fathor, 2012). Industrialisasi setidaknya dapat mengikis banyak tradisi yang berjalan sekian tahun. Sedangkan kebudayan memiliki pengaruh yang sangat besar bagi pembentukan kepribadian dan sikap hidup manusia. Dalam kebudayaan itu terdapat norma-norma dan nilai-nilai yang mengatur tingkah laku manusia dalam masyarakat. Kepribadian tidak dapat dipahami terlepas dari nilai-nilai dan norma-norma kebudayaan tersebut (Arifin, 2004). 
Dalam rangka untuk mengenang jasanya, meneladani dan menghormati ajaran serta perilakunya maka sampai sekarang masyarakat Desa Kedungwungu tetap melestarikan ritual haul, disamping makam Ki Newes tersebut juga terdapat makam istrinya yang dimakamkan di sebelahnya.

Meskipun zaman sudah modern di desa ini masih tetap mempertahankan kebiasaan-kebiasaan yang sudah mendarah daging pada masyarakat Desa Kdungwungu semisal haul, tradisi yang masih eksis dan tetap dilestarikan oleh masyarakat Desa Kedungwungu adalah haul Ki Newes yang biasa diadakan setiap tahun sekali yang dihadiri oleh masyarakat sekitar.

\section{Metode Penelitian}

Penelitian ini menggunakan pendekatan dengan metode kualitatif deskriptif dan didukung oleh teori tindakan Max Weber yang sesuai dengan permasalahan dalam penelitian ini. Dengan metode dan teori ini akan mampu menjelaskan dan mencari datadata mengenai tokoh Ki Newes serta Haul Ki Newes yang ada di Desa Kedungwungu Kecamatan Krangkeng Kabupaten Indramayu tersebut. Sehingga akan diketahui apakah benar-benar sesuai dengan fakta yang ada.

\section{Hasil dan Pembahasan}

Berdasarkan pengamatan peneliti di lapangan dan setelah mendatangi beberapa tokoh yang dijadikan sumber, keberadaan atau asal usul diadakannya tradisi haul Ki Newes di Desa Kedungwungu sampai saat ini belum diketahui secara pasti mengenai tahun dan tanggal dicetuskannya. Acara haul ini sudah turun-temurun dari nenek moyang sebelumnya. (Muin, 2008) selaku salah satu sesepuh dan juga tokoh di desa ini, menjelaskan, "Jangankan saya, orang-orang sebelum saya kalau ditanyakan tentang asal usul adanya haul Ki Newes tidak akan tahu. Diadakannya haul tidak lain kecuali sebagai ungkapan terima kasih kepada Allah, karena berkat leluhur yang telah babat desa ini bisa ada."

Haul Ki Newes dilakukan di dusun satu RT 03/ RW 01 disebuah makam yang berukuran $3 \times 3^{\mathrm{m}}$ di Desa Kedungwungu. Di tempat inilah Ki Newes bersama istrinya dimakamkan, sebagai tempat peristirahatan terakhirnya. Perjalanan haul dari waktu ke waktu sampai saat ini mengalami perkembangan, terutama semangat masyarakat terhadap acara haul Ki Newes itu sangat tinggi. Dukungan dan partisipasi masyarakat yang sampai saat ini menjadi hal yang penting demi terlaksana dan eksisnya sebuah kearifan lokal, yaitu haul Ki Newes ini. 


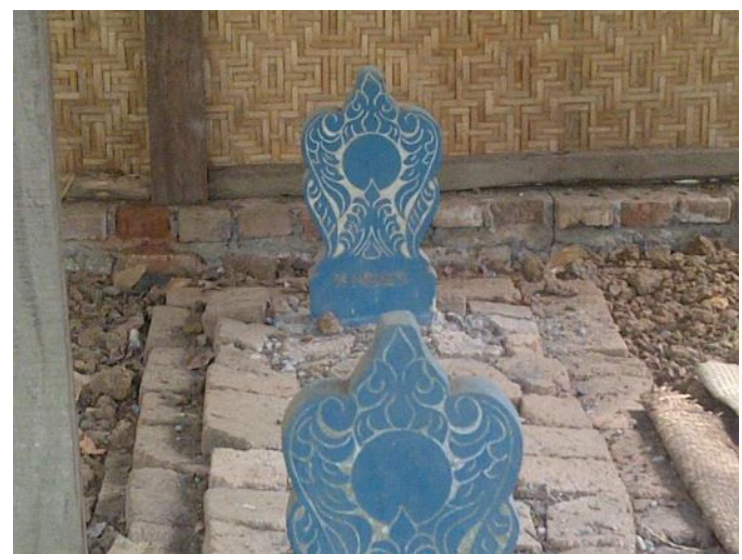

Gambar 1

Makam Ki Newes

Haul diadakan setiap bulan Robiul tsani (syawal mulud). Pada mulanya acara haul diadakan dengan cara berbeda dengan acara yang ada pada saat ini. Bentuk aacara haul diantaranya sejak pagi sekitar jam 07.30 WIB diadakan pembacaan Maulid Al Barzanzi (Marhabanan) oleh ibu-ibu jam'iyah Qur'an dan jamiyah Maulid Al Barzanzi dan masyarakat Desa Kedungwungu, dilanjutkan siang hari setelah Dzuhur dengan acara Tahlil bersama tokoh agama, masyarakat Desa Kedungwungu dan keluarga keturunan Ki Newes yang ada di sekitar Desa Kedungwungu. Dilanjutkan pada malam harinya sebelum pada acara inti diisi dengan penampilan group salawat Al-Istiqomah. Kemudian setelah Isya dilanjutkan dengan ceramah Agama. Biasanya yang mengisi ceramah agama tersebut adalah seorang dai atau kiai. Adapun tokoh-tokoh yang diundang pada acara haul Ki Newes ialah dari instansi kelembagaan, tokoh-tokoh agama, dan tokoh-tokoh masyarakat Desa Kedungwungu secara umum.

Acara haul Ki Newes sampai saat ini sudah menjadi tradisi masyarakat Desa Kedungwungu, yang diadakan secara turun-temurun mulai sejak zaman dahulu, mulai sejak sesepuh-sesepuh hingga saat ini tetap dilestarikan sebagai wujud kepedulian dan penghormatan pada leluhur yang telah mengajarkan agama Islam. Melalui tradisi haul, salah kearifan lokal ini tetap tejaga dan dilestarikan. 


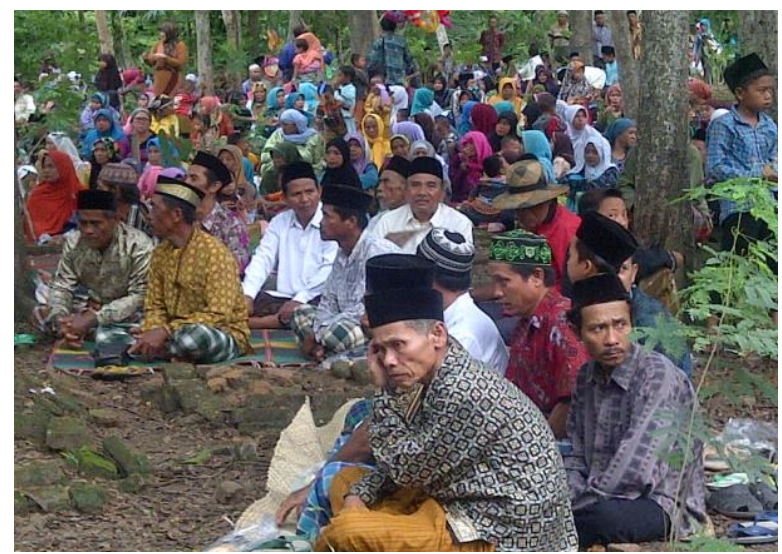

Gambar 2

Kegiatan Acara Haul Ki Newes

Tradisi haul Ki Newes dilakukan dengan tiga hal kegiatan yaitu Pembacaan Maulid Al-Barzanzi, Ziaroh kubur, dan Pengajian umum. Orang yang memberi nama Desa Kedungwungu adalah Ki Mridin dan Ki Karang. Asal mula penamaan Desa Kedungwungu adalah terdapat Balong yang sangat dalam dan luas yang dikelilingi oleh pohon wungu, maka dari itu terjadilah nama Kedungwungu. Kedung artinya balong yang dalam dan luas, wungu artinya nama pohon yang mengelilingi balong. Tokoh Ki Mridin dan Ki Karang adalah dua pemuda yang datang dari Demak yang ditugaskan oleh Ki Royani (Ki Geden Srengseng) untuk tinggal di Kedungwungu.

Bagi masyarakat Desa Kedungwungu, kegiatan tahunan yang bernama haul, merupakan ungkapan kegiatan sosial keagamaan. Hal ini dilakukan dalam bentuk berziaroh ke makam yang dipercaya ajaran agam Islam di Desa Kedunwungu. Haul dengan ziaroh kubur merupakan dua ekpresi kultural keagamaan yang memiliki kesamaan dalam kegiatan dan objeknya. Perbedaannya hanya pada pelaksanaannya saja, di mana haul biasanya ditentukan waktunya oleh pihak yang memiliki otoritas di daerah dan pelaksanaannya dilakukan secara kolektif.

Prosesi ritual haul biasanya dilakukan sejak hari Selasa pagi sekitar jam 08.00 diadakan pembacaan maulid Al-Barzanzi oleh ibu Nyai dan ibu-ibu jamiyah serta masyarakat Desa Kedungwungu sedangkan setelah zuhur acara haul Ki Newes yang bertempat di makam Ki Newes, dihadiri oleh para tokoh masyarakat, aparat pemerintahan, masyarakat Desa Kedungwungu serta masyarakat sekitar Desa Kedungwungu yang masih ada hubungan keturunan dengan Ki Newes.

Acara pada malam harinya adalah pengajian agama. Sebelum acara inti, diselingi dengan pembacaan kosidah solawat nabi oleh grup solawat Al-Istiqomah, kemudian setelah Isya dilanjutkan dengan acara ceramah keagamaan. Biasanya yang mengisi ceramah tersebut adalah salah seorang dai atau kiyai. Hal itu dilakukan sebagai ungkapan solidaritas dan ugkapan kesalehan sosial kepada sesama. Kemudian dalam acara tersebut masyarakat merayaknnya dengan tumpeng sebagai bentuk syukuran atau mensyukuri nikmat yang diberikan oleh Allah SWT. Itu yang terjadi masa-masa dahulu. Namun dewasa ini, masyarakat tidak merayakannya dengan tumpeng, tetapi juga 
dengan buah-buahan, roti, kue dan sebagainya. Hal tersebut dilakukan supaya nasi yang diberikan masyarakat tidak mubazzir.

Dari kegiatan haul Ki Newes dapat dilihat bahwa terdapat pergeseran motivasi seseorang dalam melakukan kegiatan keagamaan. Menurut (Sztompka, 2011) terjadi suatu pergeseran tekanan ke arah keyakinan, motivasi, dan tujuan pada diri anggota masyarakat, yang semuanya memberi isi dan bentuk kepada tindakannya. Kata tindakan dipakai oleh Weber untuk perbuatan-perbuatan yang bagi sipelaku mempunyai arti subyektif. Mereka dimaksudkan, pelaku hendak mencapai suatu tujuan yang ingin dicapainya, atau ia didorong oleh motivasi. Tindakan akan menjadi sosial menurut Weber, bilamana itu terjadi hanya kalau arti maksud subyektif dari tingkahlaku membuat individu memikirkan dan menunjukkan suatu keseragaman yang bermakna. Pelaku individual mengarahkan kelakuannya kepada penetapan-penetapan atau harapanharapan tertentu yang berupa kebiasaan umum atau dituntut dengan tegas atau bahkan dibekukan dengan undang-undang.

Dalam pandangan Max Weber pelestarian tradisi haul Ki Newes yang terdapat di Desa Kedungwungu adalah bagian dari suatu ilmu yang dengannya mampu memberikan pemahaman-pemahaman terhadap tindakan sosial dengan cara menerangkan dan menguraikan dan sebab-sebab tindakan sosial yang ada. Jadi, pandangan Weber bukan dari bentuk substansialnya melainkan yang dilakukan secara subjektifnya, tindakan yang dilakukan Weber disini adalah tindakan-tindakan yang nyata dari perseorangan yang timbul dari alasan-alasan subjektif.

Salah satu tindakan yang termasuk dalam kategori tindakan tradisional adalah tradisi haul Ki Newes di Desa Kedungwungu. Tradisi ini merupakan tindakan sosial yang didorong dan berpedoman kepada tradisi-tradisi yang telah terjadi pada masa lampau atau kebiasaan-kebiasaan yang berkembang di masa lalu. Biasanya tindakan yang seperti ini, cara-cara yang dilakukan selalu bersandar terhadap hukum-hukum yang sifatnya umum dan lazim dilakukan dalam kehidupan masyarakat.

Memang pada dasarnya menurut Weber setiap perilaku sosial dapat mengandung makna tersendiri terlepas apakah atau beberapa orang memberikan arti lebih terhadap perilaku tersebut. Dari itu semua yang paling penting dari adanya tradisi haul di Desa Kedungwungu termasuk bagian dari perilaku sosial yang mempunyai tujuan yang jelas sehingga yang akan dipergunakan dalam tujuan tersebut juga lebih jelas.

Ritual dalam Haul Ki Newes merupakan tindakan sosial. Selain tindakannya yang nyata-nyata telah diarahkan kepada orang lain, juga termasuk tindakan yang bersifat membatin atau bersifat subjektif yang mungkin terjadi karena adanya pengaruh positif dari situasi tertentu. Atau mungkin ritual haul Ki Newes merupakan tindakan yang sering diulang secara sengaja akibat dari situasi yang serupa.

Jadi, realitas ini (tradisi Haul Ki Newes) sudah menjadi kebiasaan dalam struktur sosial masyarakat setempat. Ritualitas ini sebagai warisan leluhur nenek moyang yang dipercaya ada unsur keagamaan dari para pendahulu dari generasi ke generasi sehingga masyarakat menjadikan pada tindakan ini sebagai bagian yang tidak bisa dipisahkan dari kehidupannya bersifat (membatin), sebagai warisan leluhur serta diyakini oleh 
masyarakat Desa Kedungwungu. Weber menyebutnya sebagai traditional action, di mana tindakan masyarakat Desa Kedungwungu di dasarkan pada kebiasaan-kebiasaan yang dilakukan dengan turun-temurun dari para pendahulu mereka.

\section{Kesimpulan}

Upacara haul Ki Newes yang sekarang terdapat di Desa Kedungwungu Kecamatan Krangkeng Indramayu adalah salah satu tradisi yang sampai saat ini tetap bertahan meskipun berada di tengah modernisasi teknologi. Hal ini disebabkan selain telah mendapat pengakuan dari masyarakat setempat, keberhasilan tersebut dipengaruhi oleh beberapa faktor yang ikut mendukung pelestarian haul tersebut. Pandangan masyarakat Desa Kedungwungu Kecamatan Krangkeng Indramayu pada tradisi haul Ki Newes adalah sebagai wujud kepedulian dan penghormatan pada leluhur yang telah berjuang dan berkorban menyebarkan agama Islam, menyampaikan doanya untuk mendapatkan keselamatan dan keberkahan, sebagai dharma bakti masyarakat Desa Kedungwungu Krangkeng Indramayu yakni berupa takziyah ke makam Ki Newes, untuk mengenang jasa dan perjuangan serta bentuk ucapan rasa terima kasih kepada Ki Newes selaku orang pertama yang menyebarkan agama Islam desa ini. 


\section{BIBLIOGRAFI}

Arifin, M. (2004). Psikologi dakwah: suatu pengantar studi. Bumi Aksara.

Fathor, Fathor. (2012). Mempertahankan Tradisi di Tengah Industrialisasi: studi kasus pelestarian tradisi haul mbah Sayyid Mahmud di desa Karangbong kecamatan Gedangan kabupaten Sidoarjo. UIN Sunan Ampel Surabaya.

Hoeve, Van. (2003). Insklopedia Islam (Cet. Ke-11). Jakarta: PT Ictiar Baru.

Mufidah, Umi. (2016). Studi tentang Upacara Haul dan dampaknya terhadap kehidupan masyarakat di desa Wates kecamatan Tanggulangin Sidoarjo. UIN Sunan Ampel Surabaya.

Muin, KH. Mustofa Abdul. (2008). Silsilah Ki Newes. Tidak diterbitkan.

Purwanto, S. U. (2007). Sosiologi Untuk Pemula. Yogyakarta: Media Wacana.

Putri, Kiti Tiara. (2018). KH. Abdullah Zawawi Izhom (1930-2013) Biografi dan Peranannya dalam Perkembangan Islam di 1 Ilir Palembang.

Qomariyah, Alfi. (2019). Penerapan Nilai-Nilai Etika Bisnis Islam Dalam Pengelolaan Wisata Religi Di Cirebon (Studi Kasus: ObjekWisataMakam Sunan Gunung Jati).

Soekanto, Soerjono. (2009). Sosiologi suatu pengantar, edisi baru. Jakarta: Rajawali Pers.

Sztompka, Piotr. (2011). Sosiologi perubahan sosial (cetakan keenam). Jakarta: Prenada Media Group. 